\title{
Mobile learning use in the classroom: approaches to the teaching and learning process
}

Neri de Souza Santana - nerisouzasantana@gmail.com - PPGEN-UENP Annecy Tojeiro Giordani - annecy@uenp.edu.br - PPGEN-UENP Selma dos Santos Rosa - selmasantos@ufpr.br - PPGEN - UENP / UFPR Joao Coelho Neto - joaocoelho@uenp.edu.br - PPGEN-UENP

\begin{abstract}
Considering how Mobile Digital Technologies can assist in the teaching and learning process, in the most diverse areas of Teaching. This paper results from a Systematic Literature Review on the use of Mobile Learning in teaching and learning. Thereby, we identified its central characteristics, which refers to the use of mobile devices, and mapped out areas of Education and Teaching that have been using the MLearning in their educational activities in school scope. The methodological referral used was the Systematic Literature Review, over a period of 10 years, from 2007 to 2017, on the Theses and Dissertations Bank from Coordination for the Improvement of Higher Education Personnel (CAPES), on Capes Periodic Bank and in the periodic listed in the restricted index (A1, A2 and B1) in the Teaching area of the WebQualis platform Quadrennial Periodic Classifications 2013-2016. The results are an even small number of effective use of Mobile Learning in school scope, although there is evidence that its using is feasible in classrooms due to its characteristics of working with portable and simple devices, commonly used by students in personal life, not implying in additional costs.
\end{abstract}

Keywords: mobile learning. Mobile learning. Teaching and learning.

\section{Uso do Mobile Learning em sala de aula: possíveis aproximações para o processo de ensino e de aprendizagem}

Resumo - Tendo em vista que as Tecnologias Digitais Móveis podem auxiliar no processo de ensino e de aprendizagem, nas mais diversas áreas de Ensino, esse artigo resulta de uma Revisão Sistemática da Literatura sobre o uso do Mobile Learning no ensino e de aprendizagem. Dessa forma, identificamos suas características centrais, que concernem ao uso de dispositivos móveis, e mapeamos áreas de Educação e Ensino que se utilizam do M-Learning em suas atividades educacionais no âmbito escolar. $\mathrm{O}$ encaminhamento metodológico utilizado foi o da Revisão Sistemática de Literatura, em um intervalo de 10 anos, percorrendo os anos de 2007 a 2017, no banco de teses e dissertações da Coordenação de Aperfeiçoamento de Pessoal de Nível Superior, no Banco de Periódicos da referida coordenação e nas revistas listadas no índice restrito (A1, A2 e B1) na área de Ensino da plataforma WebQualis - Classificações de Periódicos Quadriênio 2013-2016. Os resultados apontam um número ainda pequeno do uso efetivo do Mobile Learning no âmbito escolar, porém há evidências de que seu uso seja viável nas salas de aula por sua característica de trabalho por meio de dispositivos portáteis simples, comumente utilizados no dia a dia, não acarretando custos adicionais.

Palavras-chave: Mobile Learning. Aprendizagem móvel. Ensino e aprendizagem.

\section{Introduction}

The widespread use of mobile devices presents a great potential for the development of applications that answer the needs in education (Mobile Learning). Throughout the last decades, we have faced the emergence of a connected mobile society, 
with a variety of sources of information, technologies and available modes of communication (Cordenonzi, 2013).

According to the United Nations Educational, Scientific and Cultural Organization (Unesco, 2014), M-learning is the use of mobile technology alone or in combination with other Digital Information and Communication Technologies (DICT), which enables learning anytime, anywhere. This mode of teaching includes the use of mobile tools, such as the case of mobile phones, tablets and other small devices that can be easily transported anywhere.

DICT are increasingly present in people's professional and daily activities. Thus, with the advent of globalization, this information is made widely available (Silva, Marques, 2011), thereby requiring the use of different digital resources to process information in an efficient and practical manner.

M-learning has become so relevant as an innovation tool in school environments that it has been studied by Unesco (Unesco, 2014) with the intention of disseminating resources and solutions to make it possible for teachers to implement it with their students. Thus, for Fonseca (2013), mobile devices are convergent, portable and multimedia, presenting great potential to be explored in learning.

Considering the above and the possibility of using mobile technologies in teaching, this study proposes, through a Systematic Literature Review, to identify papers that approach technology-based teaching and learning in the most diverse areas of knowledge and then envision reviewing the theme, outlining the possibility and feasibility of future research. The research period was from 2007 to 2017.

The present study is divided into five sections: the first section contextualizes the paper; in the second section we introduce the materials and methods employed and the protocol of literature review, in the third section we present the inclusion and exclusion criteria, in the fourth section we expose the results and discussions, and in the fifth section we draw the final considerations and perspectives of other studies.

\section{Materials and methods}

This research, of a qualitative nature, is based on the proposition that the study objects are not reduced to simple variables, but represented in their totality, within their everyday contexts (Flick, 2009). This research is based on adaptations of the defined steps of Kitchenham's Systematic Literature Review (SLR) method (Kitchenham, 2004), which considers that a review aims at identifying, evaluating and interpreting all relevant research to respond to a specific research focus, being the systematic review a form of secondary study. We question: Which educational areas are already using Mobile Learning in the classroom? Which digital educational tools have been used?

\section{Systematic Literature Review Protocol}

For the purposes of SLR, papers available in databases were included in the thesis and dissertations database of the Theses and Dissertations Bank from Coordination for the Improvement of Higher Education Personnel (CAPES), in the Capes Periodic Bank and in journals that are in the restricted index (A1, A2 and B1) in the Teaching area of the WebQualis platform - Quadrennial Periodic Classifications 2013-2016. Ten years was the delimitation of the research time, that is, between 2007 and 2017. The languages delimited for the research were English and Portuguese, being the descriptor, "Mobile Learning" in English and "aprendizagem móvel" in Portuguese.

The first selection was made at Thesis and Dissertation CAPES, resulting in a very expressive number of articles, 5,237 for "Mobile Learning" and 1,977 results for "aprendizagem móvel". Thus, we assumed that our guiding question: "Which educational areas are already using Mobile Learning", should be very specific to find the areas that 
have already been using mobile learning in the classroom. Through search refinement, key word efficiency and by reading the abstracts, we selected 17 research papers.

The second selection was at the CAPES Periodic Bank website, based on defined descriptors used to find studies that indicated the use of mobile technology in its context; for that, searches were conducted both in Brazilian and international journals, in Portuguese and English, resulting in papers in these two languages, culminating in a number of 983 selected ones. After reading the titles, 101 articles remained, which were then filtered by reading their abstracts and, subsequently, narrowed down through the reading of the studies as a whole, finding, therefore, only 5 results within our scope.

For the third research, the study conducts a research of scientific productions published in journals qualified as A1, A2 and B1 in the WebQualis platform in 2016, in Education, covering the search interval of the last ten years. The analysis was performed in Portuguese and English language journals, which were listed, with selection based on the concentration on mobile technologies, with an initial result of 7,214 papers. After that, a detailed visual reading and analysis of the titles of the papers, covering the keywords "mobile learning" and "aprendizagem móvel", followed by the one-to-one abstract readings summarized in the magazines publications in the last decade, led to the exclusion process, to exempt studies that did not deal with the use of Mobile Learning effectively in teaching and learning for later reading and analysis. Special attention was given to the abstract when the use of mobile learning was unclear in the title. As a result, we obtained 465 articles, from 16 journals, in the interval of ten years.

\section{Inclusion and exclusion criteria}

The number of articles found in the three search platforms resulted in a total of 10,174 papers, which led us to an initial analysis of the adequacy of the demand for papers related to Mobile Learning that would answer the interest of this research. Then, from the readings of titles and keywords, the result was 583 articles to be analyzed. According to Sampaio and Mancini (2007), the researcher performing an SLR must ensure that all texts that are important or that may have a relevant impact on the research are included, while those which are not in accordance with the objectives of the research are excluded.

For this review to be fulfilled, some steps defined by Kitchenham (2004) were listed and adapted. Regarding Research Identification and Planning, the guiding questions listed in this paper, aimed at structuring actions for the search and interpretation of the results, were: How is Mobile Learning already being used in the teaching and learning process? What are the areas currently using such technology in the classroom? Which mobile devices have been used? Where has mobile learning been used in classroom?

Following these guidelines, we chose the articles that answer the criteria mentioned above and as a result, of the 583 preselected articles, 568 were excluded, remaining a total of 15 articles. The main reasons for the exclusions were: papers that focused on Mobile Learning in teaching and learning only as a research source or proposition of its use; papers that focused on its use in areas other than Teaching or Education; papers that approached the proposition or construction of applications directed to teaching and learning. Therefore, we kept focused on the papers that reported the effective use of mobile learning in the classroom, with activities prepared to use this technology in real scenarios with students.

\section{Results}

In this section we present the analysis of the results obtained following the guidelines presented in the Research Methodology. Table 1 shows the 3 papers selected 
for the analysis through the complete reading of them in the Capes Theses and Dissertations Bank; in table 2 the survey of the papers in Capes - CAPES Periodic Bank; in table 3 the survey of the relevant literature in WebQualis journals selected after exclusion criteria and in table 4 the 7 articles selected for analysis in the abovementioned journals.

\subsection{Capes Theses and Dissertations Bank}

In this section we present the analysis of the results obtained following the guidelines presented in the Research Methodology. Table 1 shows the 3 papers selected for the analysis, in the CAPES theses and dissertations bank, after the due exclusions.

Table 1- Papers - Theses and Dissertations CAPES

\begin{tabular}{|c|c|c|c|c|c|}
\hline N. & Searched paper title & $\begin{array}{c}\text { Author / } \\
\text { year }\end{array}$ & $\begin{array}{c}\text { Research program / } \\
\text { knowledge area / Local }\end{array}$ & Type & $\begin{array}{c}\text { Knowledge } \\
\text { area }\end{array}$ \\
\hline 1 & $\begin{array}{l}\text { Tecnologia móvel no } \\
\text { Ensino e Aprendizagem de } \\
\text { língua inglesa na escola }\end{array}$ & $\begin{array}{l}\text { Liz, Nevton } \\
\text { de. } 2015 .\end{array}$ & $\begin{array}{c}\text { Ensino de Ciências } \\
\text { Humanas, Sociais e da } \\
\text { Natureza - (UTFPR)/ } \\
\text { Paraná }\end{array}$ & Dissertation & $\begin{array}{l}\text { English } \\
\text { language } \\
\text { teaching }\end{array}$ \\
\hline 2 & $\begin{array}{l}\text { MC-Learning: práticas } \\
\text { colaborativas na escola } \\
\text { com o suporte da } \\
\text { tecnologia móvel }\end{array}$ & $\begin{array}{l}\text { Nascimento, } \\
\text { Karla } \\
\text { angélica } \\
\text { silva. } 2016 .\end{array}$ & $\begin{array}{c}\text { Educação - UFC / } \\
\text { Ceará }\end{array}$ & Thesis & $\begin{array}{l}\text { Education / } \\
\text { Science }\end{array}$ \\
\hline 3 & $\begin{array}{l}\text { Mediação tecnológica } \\
\text { baseada em Mobile } \\
\text { Learning para o ensino de } \\
\text { biologia: processo de } \\
\text { aprendizagem e } \\
\text { intervenção no terceiro } \\
\text { ano do ensino médio }\end{array}$ & $\begin{array}{l}\text { Monteiro, } \\
\text { Joesio } \\
\text { Barbosa. } \\
2016 .\end{array}$ & $\begin{array}{c}\text { Gestão e tecnologias } \\
\text { aplicadas à educação - } \\
\text { Universidade do } \\
\text { Estado da Bahia / } \\
\text { Bahia }\end{array}$ & Dissertation & Science \\
\hline
\end{tabular}

Resource: The authors (papers selected in the Thesis and Dissertations database CAPES).

Following, the data results analysis in Table 1:

- Liz (2015) presents a teaching proposal aimed at High School students in which the use of Mobile Learning contributes to the improvement of the study of the English Language, through smartphones and tablets. This way, the strategy has maximized the acquisition of language skills and competences, in a fun and motivating way.

- Nascimento (2016) presents a study of how the teaching action related to Mobile Learning influenced the development of a pedagogical project, articulating curricular content, mobile technologies and real situations lived in the community with students of the 7th grade of a Brazilian public school, in science. The results indicate that the teaching practices supported by mobile devices are motivating and differentiated.

- Monteiro (2016) worked with mobile devices as elements of didactic intervention in the teaching-learning process during the years of 2015 and 2016 with the students of the 3rd year of High School. The results demonstrated that the teaching mediated by a participatory applied research approach, made the understanding and the theoretical and practical learning relations of the Genetics discipline more flexible.

We conclude that working with M-Learning has a great potential to be satisfactory, since studies show that student learning becomes more fun and motivating, as well as the ease in working with these devices. Research has also shown the importance of the teacher as a monitor in this process. In summary, it is well known that the studies analyzed share the same view that working with Mobile Learning is a great option in teaching and learning.

\subsection{Capes Periodic Bank}


At first, 101 articles were returned, but after the necessary exclusions it resulted in 5 papers that would fit the scope of this research. This is shown in Table 2 below.

Table 2 - Papers searching in Capes Periodic Bank

\begin{tabular}{|c|c|c|c|c|}
\hline $\mathrm{N}$ & Author/Local & Research paper title & $\begin{array}{c}\text { Journal/ Volume/ } \\
\text { number/year }\end{array}$ & $\begin{array}{c}\text { Knowledg } \\
\text { e area }\end{array}$ \\
\hline 1 & $\begin{array}{l}\text { Ribeiro, Guilherme } \\
\text { Augusto Maciel et al. } \\
\text { Espirito Santo, Brazil. }\end{array}$ & $\begin{array}{l}\text { O uso de tecnologias móveis no } \\
\text { ensino de ciências: uma } \\
\text { experiência sobre o estudo dos } \\
\text { ecossistemas costeiros da mata } \\
\text { atlântica sul capixaba. }\end{array}$ & $\begin{array}{l}\text { Revista Ibero- } \\
\text { Americana de } \\
\text { Estudos em } \\
\text { Educação, V.11, } \\
\text { n.4, } 2016 .\end{array}$ & Science \\
\hline 2 & $\begin{array}{l}\text { Dias, Daniele Dos Santos } \\
\text { Ferreira; de Deus, } \\
\text { Milene Maria Machado; } \\
\text { Ireland, Timothy Denis. } \\
\text { / Paraíba, Brazil. }\end{array}$ & $\begin{array}{l}\text { A contribuição do uso de } \\
\text { dispositivos móveis para um } \\
\text { currículo voltado a uma educação } \\
\text { transformadora na EJA. }\end{array}$ & $\begin{array}{l}\text { Revista Espaço do } \\
\text { Currículo - V.6 n. } \\
\text { 2, } 2013 .\end{array}$ & $\begin{array}{l}\text { Education } \\
\text { of Young } \\
\text { adults. }\end{array}$ \\
\hline 3 & $\begin{array}{l}\text { Taylor, J. D. et al. / } \\
\text { Leeds, UK. }\end{array}$ & $\begin{array}{c}\text { Developing } \\
\text { a Mobile Learning Solution for } \\
\text { Health and Social Care Practice }\end{array}$ & $\begin{array}{c}\text { Distance } \\
\text { Education, V. } 31 \\
\text { n. } 2,2010 .\end{array}$ & $\begin{array}{l}\text { Education / } \\
\text { Health }\end{array}$ \\
\hline 4 & $\begin{array}{l}\text { Shohel, M. Mahruf C. ; } \\
\text { Power, Tom. / } \\
\text { Bangladesh. }\end{array}$ & $\begin{array}{l}\text { Introducing Mobile Technology } \\
\text { for Enhancing Teaching } \\
\text { and Learning in Bangladesh: } \\
\text { Teacher Perspectives. }\end{array}$ & $\begin{array}{c}\text { Open Learning, V } \\
.25, \text { n. } 3,2010 .\end{array}$ & $\begin{array}{l}\text { English } \\
\text { Language } \\
\text { Teaching }\end{array}$ \\
\hline 5 & $\begin{array}{l}\text { Basoglu, Emrah Baki ; } \\
\text { Akdemir, Omur. / } \\
\text { Turkey. }\end{array}$ & $\begin{array}{l}\text { A Comparison of Undergraduate } \\
\text { Students' English } \\
\text { Vocabulary Learning: } \\
\text { Using Mobile Phones and Flash } \\
\text { Cards. }\end{array}$ & $\begin{array}{c}\text { Turkish Online } \\
\text { Journal of } \\
\text { Educational } \\
\text { Technology - } \\
\text { TOJET, V. } 9 \text { n. } 3 \text {, } \\
2010 .\end{array}$ & $\begin{array}{l}\text { English } \\
\text { Language } \\
\text { Teaching }\end{array}$ \\
\hline
\end{tabular}

Source: The authors (Selected papers in Capes Periodic Bank)

- Ribeiro (2016) developed a didactic sequence based on the three pedagogical moments of Delizoikov et at. (2002), supported by mobile technologies in the study of the coastal ecosystems of Atlantic Forest with students from a public school. He used the mobile devices in a field class in the identification of the fauna and flora through his own application. The students demonstrated motivation and interest.

- Dias; Deus and Ireland (2013) present reflections on the importance of using mobile devices, especially the smartphone, as a facilitator in the process of reading acquisition and digital inclusion. The expected results refer to a socially active subject, who understands technology as a contributing instrument to acquiring knowledge.

- Taylor et al (2010) share their experiences of an innovative, five-year, large-scale program to introduce mobile learning in learning and assessment of Health and Social Care (H\&SC) implementation that overcomes the division that exists between the university classroom and the practice setting in which these students learn. The results have demonstrated great acceptance and motivation by using these devices for learning.

- Shohel, Mahruf and Power (2010) discuss emerging issues in the experiences of teachers in Banglades while participating in a professional development program in English language teaching. Teachers participating in this study reflect six months of experience in the use of professional development materials all accessed through portable digital media players and were motivated to work all the learning with their students soon.

- Basoglu, Baki and Omur (2010) demonstrated the effects of using English vocabulary learning programs on students' mobile phones in a research project with students of a Graduate Preparatory Program at a public university in Turkey. The results 
indicated that the use of mobile phones as a vocabulary learning tool is more effective than one of the traditional vocabulary learning tools.

The papers showed positive results demonstrating more interest and motivation by the students and innovation in the way of teaching and learning.

\subsection{WebQualis Platform}

Concerning Qualis A1, a total of 146 journals were found, with 139 being excluded and only 7 remaining, since the others did not present results referring to the scope of this research. With Qualis A2 the results were 199 journals, with 194 being excluded after their analysis, remaining only 5 that contained articles relevant to this study. In relation to Qualis B1, 367 journals were found, but after reading and refinement of research there were only 4 magazines that met the purpose of our searches.

In Qualis A1, A2 and B1, a total of 1,347 journals scored in the Teaching area. There was a total of 693 exclusions from titles readings, remaining only 16 journals to be analyzed. Table 3 summarizes the results of the research fulfilled in these journals.

Table 3 - Paper searching in the selected journals from 2007 to 2017

\begin{tabular}{|c|c|c|c|c|c|c|}
\hline $\mathrm{N}$ & Journal & $\begin{array}{l}\text { Qua } \\
\text { lis }\end{array}$ & ISSN & $\begin{array}{l}\text { Total of } \\
\text { searched } \\
\text { papers }\end{array}$ & $\begin{array}{l}\text { Total of papers } \\
\text { that approached } \\
\text { the thematic }\end{array}$ & Language \\
\hline 1 & $\begin{array}{c}\text { Advances in Physiology } \\
\text { Education }\end{array}$ & A1 & $1043-4046$ & 77 & 1 & English \\
\hline 2 & $\begin{array}{c}\text { Biochemistry and molecular } \\
\text { biology education }\end{array}$ & A1 & $1470-8175$ & 89 & 0 & English \\
\hline 3 & $\begin{array}{l}\text { Early childhood education } \\
\text { journal }\end{array}$ & A1 & $1082-3301$ & 26 & 0 & English \\
\hline 4 & $\begin{array}{l}\text { International journal of distance } \\
\text { education technologies }\end{array}$ & A1 & $1539-3100$ & 17 & 0 & English \\
\hline 5 & $\begin{array}{l}\text { International journal of } \\
\text { mathematical education in } \\
\text { science and technology }\end{array}$ & A1 & 0020-739X & 40 & 0 & English \\
\hline 6 & $\begin{array}{l}\text { International Journal of science } \\
\text { Education }\end{array}$ & A1 & 0950-0693 & 72 & 1 & English \\
\hline 7 & $\begin{array}{c}\text { Journal of Science Education } \\
\text { and Technology }\end{array}$ & A1 & $1059-0145$ & 82 & 0 & English \\
\hline 8 & $\begin{array}{c}\text { Acta Scientiae: revista de } \\
\text { ensino de ciências e matemática }\end{array}$ & $\mathrm{A} 2$ & $2178-7727$ & 1 & 0 & English \\
\hline 9 & Acta Scientiarum Education & A2 & $2178-5201$ & 1 & 0 & English \\
\hline 10 & $\begin{array}{c}\text { Amazônia - revista de educação } \\
\text { em ciências e matemáticas }\end{array}$ & $\mathrm{A} 2$ & $2317-5125$ & 1 & 0 & Portuguese \\
\hline 11 & $\begin{array}{l}\text { Revista brasileira de Ensino de } \\
\text { ciência e tecnologia }\end{array}$ & $\mathrm{A} 2$ & $1982-873 X$ & 7 & 0 & Portuguese \\
\hline 12 & $\begin{array}{l}\text { Revista tempos e espaços em } \\
\text { Educação }\end{array}$ & $\mathrm{A} 2$ & $2358-1425$ & 5 & 0 & Portuguese \\
\hline 13 & $\begin{array}{c}\text { Revista Educação e tecnologia - } \\
\text { UTFPR }\end{array}$ & B1 & $2179-6122$ & 1 & 0 & Portuguese \\
\hline 14 & $\begin{array}{l}\text { Revista Novas Tecnologias na } \\
\text { Educação - Renote }\end{array}$ & B1 & 1679-1916 & 30 & 5 & Portuguese \\
\hline 15 & $\begin{array}{l}\text { Revista tecnologias na } \\
\text { educação }\end{array}$ & B1 & $1984-4751$ & 17 & 0 & Portuguese \\
\hline 16 & $\begin{array}{c}\text { TEAR - Revista de educação, } \\
\text { ciência e tecnologia }\end{array}$ & B1 & $2238-8079$ & 0 & 0 & Portuguese \\
\hline \multicolumn{4}{|c|}{ Total of searched and selected papers } & 466 & 7 & \\
\hline
\end{tabular}

Source: The authors (Journals from the WebQualis Platform)

Table 4 presents the results of the research by papers published in the 16 selected journals, in Education between 2007 and July 2017, classified in the WebQualis platform 
as A1, A2 and B1, in Qualis 2016. Of the 466 articles found 7 (seven) of them dealt with the effective use in the classroom of Mobile Learning, revealing the low number of publications which met our research criterion. About the articles found, a brief analysis follows:

Table 4 - Papers from the 7 selected journals

\begin{tabular}{|c|c|c|c|c|c|}
\hline $\mathrm{N}$ & $\begin{array}{l}\text { Journal } \\
\text { State/Country }\end{array}$ & $\begin{array}{l}\text { Vol./ } \\
\text { Num./ } \\
\text { year }\end{array}$ & Authors & Title & $\begin{array}{l}\text { Knowledge } \\
\text { area }\end{array}$ \\
\hline 1 & $\begin{array}{l}\text { Advances in } \\
\text { Physiology } \\
\text { Education. / } \\
\text { California, USA. }\end{array}$ & $\begin{array}{l}83 \\
2013 .\end{array}$ & $\begin{array}{c}\text { Longmuir, Kenneth } \\
\text { J. }\end{array}$ & $\begin{array}{c}\text { Interactive computer- } \\
\text { assisted instruction in acid- } \\
\text { base physiology for mobile } \\
\text { computer platform }\end{array}$ & Health \\
\hline 2 & $\begin{array}{l}\text { International } \\
\text { Journal of science } \\
\text { Education. / } \\
\text { Cyprus. }\end{array}$ & $\begin{array}{l}38,4 \\
2016\end{array}$ & $\begin{array}{c}\text { Zacharia, Zacharias } \\
\text { C. }\end{array}$ & $\begin{array}{l}\text { The use of mobile devices } \\
\text { as means of data collection } \\
\text { in supporting elementary } \\
\text { school students' } \\
\text { conceptual understanding } \\
\text { about plants. }\end{array}$ & Science \\
\hline 3 & $\begin{array}{c}\text { Revista Novas } \\
\text { Tecnologias na } \\
\text { Educação - Renote. } \\
\text { / Rio grande do sul, } \\
\text { Brazil. }\end{array}$ & $\begin{array}{l}14,01 \\
2016\end{array}$ & $\begin{array}{l}\text { Iahnke, Silvana } \\
\text { Letícia Pires; } \\
\text { Botelho, Silvia } \\
\text { Silva da Costa; } \\
\text { Ferreira, André } \\
\text { Luís Andrejew. }\end{array}$ & $\begin{array}{l}\text { Colmeias: Um estudo de } \\
\text { caso na Matemática. }\end{array}$ & Mathematics \\
\hline 4 & $\begin{array}{c}\text { Revista Novas } \\
\text { Tecnologias na } \\
\text { Educação - Renote. } \\
\text { / Rio Grande do } \\
\text { Sul, Brazil. }\end{array}$ & $\begin{array}{l}11,01 \\
2013\end{array}$ & $\begin{array}{l}\text { Barbosa, Débora } \\
\text { Nice Ferrari; } \\
\text { Bassani, Patrícia } \\
\text { Brandalise. }\end{array}$ & $\begin{array}{c}\text { Em direção a uma } \\
\text { aprendizagem mais lúdica, } \\
\text { significativa e } \\
\text { participativa: experiências } \\
\text { com o uso de jogos } \\
\text { educacionais, tecnologias } \\
\text { móveis e comunidade } \\
\text { virtual com sujeitos em } \\
\text { tratamento oncológico. }\end{array}$ & Health \\
\hline 5 & $\begin{array}{l}\text { Revista Renote-- } \\
\text { Novas Tecnologias } \\
\text { na Educação./ } \\
\text { Ceará, Brazil. }\end{array}$ & $\begin{array}{l}14,02 \\
2016\end{array}$ & Marçal, Edgar et al. & $\begin{array}{c}\text { Análise do uso de } \\
\text { mensagens de celular na } \\
\text { melhoria da participação } \\
\text { de estudantes em cursos a } \\
\text { distância: um estudo de } \\
\text { caso. }\end{array}$ & $\begin{array}{l}\text { Distance } \\
\text { Education }\end{array}$ \\
\hline 6 & $\begin{array}{c}\text { Revista Novas } \\
\text { Tecnologias na } \\
\text { Educação - Renote. } \\
\text { / Rio Grande do } \\
\text { Sul, Brazil. }\end{array}$ & $\begin{array}{l}09,01 \\
2011\end{array}$ & $\begin{array}{c}\text { Batista, Silvia } \\
\text { Cristina Freitas et } \\
\text { al. }\end{array}$ & $\begin{array}{c}\text { Celular como ferramenta } \\
\text { de apoio pedagógico ao } \\
\text { cálculo. }\end{array}$ & Mathematics \\
\hline 7 & $\begin{array}{c}\text { Revista Novas } \\
\text { Tecnologias na } \\
\text { Educação - Renote. } \\
\text { / Rio Grande do } \\
\text { Sul, Brazil. }\end{array}$ & $\begin{array}{l}111 \\
01 \\
2013\end{array}$ & $\begin{array}{l}\text { Cordenonzi, } \\
\text { Walkiria et al. }\end{array}$ & $\begin{array}{l}\text { Mobile Q: Construção de } \\
\text { uma comunidade de } \\
\text { prática sobre Mobile } \\
\text { Learning. }\end{array}$ & Mathematics \\
\hline
\end{tabular}

Source: The authors (Journals from WebQualis Platform)

- $\quad$ Longmuir, (2013) demonstrates how the traditional classroom presentation of acid-base physiology in the medical school's first year curriculum has been replaced by interactive instructions for the iPad and other mobile computing platforms. Most students reported that it took less time to study the subject with this online instruction compared to the subject presented in the classroom. 
- Zacharia, (2016), examined the impact of mobile learning investigating whether the use of mobile devices for data collection during field trips outside the classroom could enhance fourth graders' learning about the parts of the flower and their functions. Findings revealed that using mobile devices for data collection enhanced students' conceptual understanding more than using traditional means of data collection.

- Iahnke; Botelho; Ferreira (2016) approach the mobile learning by being concerned with promoting a meaningful learning of the concepts of Plane and Space Geometry, in a case study in Mathematics, employing a hybrid teaching, associated with social networks, in contexts of mobility, to facilitate more meaningful learning.

- Barbosa; Bassani. (2013) present initial experiences with the use of games and mobile technologies, articulated to a virtual learning community, in the reinforcement of contents with children and adolescents in cancer treatment, to assist in this period, where it is necessary to leave school. It was concluded that the use of mobility is perceived as positive by the community, but that there is still the need to deepen research in this sense.

- Marçal et al. (2016) examined the use of SMS, that is, mobile messages, in a distance learning course with 474 students, looking to find out if using this technology could improve student participation in the course. The results show that the students who received the mobile messages had significantly better results than those who did not.

- Batista, Freitas et al (2011) exanimated how cell phones can collaborate for the learning of Differential and Integral Calculus, expanding possibilities of access to didactic materials and contributing to reflections. Next, they give an overview of the discipline in question and the methodology adopted in it. Finally, aspects related to the experience promoted were highlighted, which proved to be positive.

- Cordenonzi et al (2013) present partial results of the implementation of a Community of Practice (PC), where topics related to the use of mobile devices in education (Mobile Learning) are being discussed. It was observed a significant participation of the members considering the time of existence of the community.

- Being through games, through apps or activities developed to be used with MLearning, all the papers show positive results in the use with it for studies purposes.

\section{Final considerations}

With this Systematic Literature Review, we could point out some studies and areas that already research and believe in the efficacy of Mobile Learning, however, the results still demonstrate a lack of effective classroom work with it. Among the information cited in the tables, knowledge emerges that seeks to answer the guiding question: Which educational areas are already using Mobile Learning in teaching and learning, effectively, in the classroom? After analyzing the paper, it is noticeable that among many areas of Teaching and Education, only 15 articles, or $2.5 \%$ of the papers, are the result of effective classroom activities contemplating Mobile Learning. Of these 15 articles, $1(6.7 \%)$ is in Youth and Adult Education, 1 (6.7\%) in Distance Education, $3(20 \%)$ in English Language Teaching, 33 (20\%) in Mathematics and 4 (26.7\%) in Science.

The search revealed that the areas that apply M-Learning methods most effectively, use it for a variety of purposes and content. In Mathematics, the content of Calculus and Plan and Space Geometry with the use of cell phones was considered. In Health, the contents comprised Physiology, the evaluation in social assistance and even assistance in case of children on school leave due to oncological treatment, with the use of tablets. In English, the work focused on listening activities, vocabulary and varied 
language skills, aided by smartphone applications. The digital tools used are the laptop, the tablet and the smartphone both with class and homework purposes.

Other papers on Mobile Learning in the process of teaching and learning were found in different fields of knowledge such as Chemistry, Software Engineering, Health, Teacher Training, Astronomy and Computer Science. However, they were not the subject of this study since they focused on investigating whether mobile applications would work for learning or even build applications or bring proposals for its use in the classroom. Other studies consisted of surveys with university students to question a possible implementation of Mobile Learning. Nevertheless, actual use in class is still very small.

Abroad, we found one paper in Bangladesh, one in Turkey, one in Cyprus, one in Turkey and two in the United States of America. In Brazil, in the southern region we found 5 papers in total, 1 in Paraná and 4 in Rio Grande do Sul. In the northern region we found a total of 4 papers, 2 in Ceará, 1 in Bahia and one in Paraíba. One paper was found in the southeast region, in Espírito Santo state.

In summary, the study developed by this systematic review made a survey of the work that has been developed from the use of Mobile Learning in the classroom, in teaching and learning, considering the non-saturation of this subject and, so to speak, giving scope for further research.

\section{References:}

BARBOSA, Débora Nice Ferrari; BASSAN, Patrícia Brandalise Scherer. Em direção a uma aprendizagem mais lúdica, significativa e participativa: experiências com o uso de jogos educacionais, tecnologias móveis e comunidade virtual com sujeitos em tratamento oncológico. Revista Renote - Novas Tecnologias na Educação. Rio Grande do Sul, v. 11, n. 1, 1-10, jul 2013.

BASOGLU, Emrah Baki ; AKDEMIR, Omur. A Comparison of Undergraduate Students' English Vocabulary Learning: Using Mobile Phones and Flash Cards. Turkish Online Journal of Educational Technology - TOJET, V. 9 n. 3, 2010.

BATISTA, Silvia Cristina Freitas et al . Celular como ferramenta de apoio pedagógico ao cálculo. Revista Renote - Novas Tecnologias na Educação. Rio Grande do Sul, v. 9, n. 1, 1-10, jul 2011.

CAPES. Banco de Teses e Dissertações - Tabela de áreas do conhecimento. 2017. Disponível em http://bancodeteses.capes.gov.br/banco-teses. Acesso em 01 jun. 2017.

CAPES. Portal de periódicos - Tabela de áreas do conhecimento. 2017. Disponível em: http://www.periodicos.capes.gov.br/. Acesso em 02 jun. 2017.

CORDENONZI, Walkiria. Mobile Q Construção de uma Comunidade de Prática sobre Mobile Learning. Revista Renote - Novas Tecnologias na Educação. Porto Alegre, v. 11, n. 1, 1-10, jul 2013.

DIAS, Daniele Dos Santos Ferreira; DE DEUS, Milene Maria Machado; IRELAND, Timothy Denis. A contribuição do uso de dispositivos móveis para um currículo voltado a uma educação transformadora na EJA. Revista Espaço do Currículo. Paraíba, V.6 n. 2. 1-10, 2013.

FLICK, Uwe. Introdução à pesquisa qualitativa / Uwe Flick; tradução de Joice Elias Costa. - $3^{\mathrm{a}}$ ed. - Porto Alegre: Artmed, 2009. 405 p.

FONSECA. Ana Graciela M. F. da. Aprendizagem, Mobilidade e Convergência: Mobile Learning com celulares e smartphones. Revista Eletrônica do Programa de Pós-

Graduação em Mídia e Cotidiano. São Paulo, v. n. 2. 163-181 junho 2013.

V. $15 \mathrm{~N}^{\mathrm{o}}$ 2, dezembro, 2017 
IAHNKE, Silvana Letícia Pires; BOTELHO, Silvia Silva da Costa; FERREIRA, André Luis Andrejew. COLMEIAS: Um Estudo de Caso na Matemática. Revista Renote Novas Tecnlogias na Educação. Pelotas, v. 14, n. 1, 1-10, jul 2014.

LIZ, Nevton de. Tecnologia móvel no Ensino e Aprendizagem de língua inglesa na escola. 2015. 64 f. Dissertação (Mestrado em Ensino de Ciências Humanas, Sociais e da Natureza) - UTFPR - Londrina. 2015.

LONGMUIR, Kenneth J. Interactive computer-assisted instruction in acid-base physiology for mobile computer platforms. Revista Advances in Physiology

Education. California, doi:10.1152/advan.00083.2013. 2014.

KITCHENHAM, B. A. Procedures for Performing Systematic Reviews. Tech. Report TR/SE-0401, Keele University, 2014.

MARÇAL, Edgar et al. Análise do uso de mensagens de celular na melhoria da participação de estudantes em cursos a distância: um estudo de caso. Revista Renote Novas Tecnologias na Educação. Ceará, v. 14, n. 2, 1-10, dez 2016.

MONTEIRO, Joesio Barbosa. Mediação tecnológica baseada em Mobile Learning para o ensino de biologia: processo de aprendizagem e intervenção no terceiro ano do ensino médio. 2016. 103 f. Dissertação (Mestrado em Gestão e tecnologias aplicadas à educação) - - universidade do estado da Bahia, Bahia, 2016.

NASCIMENTO, Karla angélica silva. MC-Learning: práticas colaborativas na escola com o suporte da tecnologia móvel. 2016. 256 f. Tese (Doutorado em Educação) - UFC - Ceará, 2016.

RIBEIRO, Guilherme Augusto Maciel et al. O uso de tecnologias móveis no ensino de ciências: uma experiência sobre o estudo dos ecossistemas costeiros da mata atlântica sul capixaba. Revista Ibero-Americana de Estudos em Educação. Rio Grande do Sul, v. 11, n. 4, 1-10, 2016.

SAMPAIO, R.F.; MANCINI M.C. Estudos de revisão sistemática: um guia para síntese criteriosa da evidência científica. Revista Brasileira de Fisioterapia, São Carlos, v. 11, n. 1, p. 83-89, 2007.

SHOHEL, M. Mahruf C. ; POWER, Tom. Introducing Mobile Technology for Enhancing Teaching and Learning in Bangladesh: Teacher Perspectives. Revista Open Learning. Milton Keynes - UK, v. 25, n. 3, 1-10, 2010.

SILVA, Iza Sherolize Américo da; MARQUES, Isaac Rosa. Conhecimento e barreiras na utilização dos recursos da Tecnologia da Informação e Comunicação por docentes de Enfermagem. Journal of Health Informatics. São Paulo, v. 3, n. 1, out 2010.

Disponível em: file://C:/Users/Pichau/Downloads/127-450-2-PB.pdf. Acesso em: 27 Dez 2016.

TAYLOR, J. D. et al. Developing a Mobile Learning Solution for Health and Social Care Practice. Distance Education. Leeds Metropolitan University - Leeds-UK, v. 31, n. 2, 1-10, 2010.

UNESCO. O futuro da aprendizagem móvel: implicações para planejadores e gestores de políticas. Brasília, DF: UNESCO, 2014.

ZACHARIA, Zacharias C.; LAZARIDOU, Charalambia; AVRAAMIDOU, Lucy. The use of mobile devices as means of data collection in supporting elementary school students' conceptual understanding about plants. International Journal of science Education. V. 38 n. 4, 2016. 